\title{
PANDANGAN HUKUM ISLAM TERHADAP ADAT TOPO SALIA DI DESA MANINILI BARAT KECAMATAN TINOMBO SELATAN KABUPATEN PARIGI MOUTONG
}

\author{
Nizrah, Nasaruddin, Hamiyuddin*
}

\begin{abstract}
This research has a problem that how is the implementation of the topo salia custom in Desa Maninili Barat, Kecamatan Tinombo Selatan, Kabupaten Parigi Moutong, and what is the view of Islamic law on the topo salia custom. The research method used is a qualitative method that describes field research. In the data collection technique, the writer used the method of observation and direct interviews with informants, namely the village head and several religious figures as well as documentation. Then, the results of the research found that first the topo salia custom is a ritual that is carried out in the month of Rabiul Awal to commemorate the birthday of the Prophet Muhammad. namely on the 12th of Rabiul Awal, this tradition was carried out with the aim of rejecting calamities and making their children live and cultured. Second, according to the view of traditional Islamic law, topo salia does not contradict Islamic law because it contains Islamic values, such as deliberation, mutual cooperation, strengthening friendship, and a form of gratitude to Allah swt.
\end{abstract}

Keywords: Topo salia custom, Islamic law, Islamic 


\section{A. Pendahuluan}

Terjadinya hukum, bila dilihat dari sudut pandang perkembangan hidup manusia, itu dimulai sejak dari pribadi manusia yang diberikan karunia berupa akal dan perilaku oleh Tuhan. Perilaku yang terus-menerus dilakukan perorangan menimbulkan "kebiasaan pribadi". Apabila kebiasaan pribadi itu ditiru orang lain, maka ia akan menjadi kebiasaan orang tersebut. Lambat laun di antara orang yang satu dan orang yang lainnya di dalam kesatuan masyarakat ikut pula melaksanakan kebiasaan itu. Kemudian seluruh anggota masyarakat melakukan perilaku kebiasaan tadi, maka lambat laun kebiasaan itu menjadi "adat" dari masyarakat itu. ${ }^{1}$

Menurut Soepomo, definisi hukum adat yaitu:

Sinonim dari hukum yang tidak tertulis di dalam peraturan legislatif (unstatory law), hukum yang hidup sebagai konveksi di badan-badan hukum negara (parlemen, dewan provinsi dan sebagainya) hukum yang hidup sebagai peraturan kebiasaan yang dipertahankan di dalam pergaulan hidup, baik di kota maupun di desa-desa (costomary law). ${ }^{2}$

Dewasa ini, bila berbicara tentang adat, tidak akan habisnya adat yang di Indonesia pada umumnya, begitupun adat yang ada di Provinsi Sulawesi Tengah termasuk adat topo salia yang dilakukan oleh masyarakat tajio. Topo salia adalah tradisi turun temurun yang diadakan oleh masyarakat suku tajio. Tradisi topo salia merupakan suatu ritual yang dilaksanakan pada maulid Nabi Muhammad saw untuk menandai sebuah syukuran kesalamatan atas menginjak masa dini, yang pelaksanaanya melibatkan anak-anak yang berumur 3 sampai 6 tahun sebagai peserta adat yang di pimpin oleh ina-ina (pemangku adat). Dan juga dalam pelaksanaan adat ini menggunakan alat music kakula. Adapun bentuk pelaksanaannya bersifat kekeluargaan, gotong royong antar sesama. Keyakinan ini telah lama

${ }^{1}$ Tolib Setiady, Intisari Hukum Adat Indonesia Dalam Kajian Kepustakaan, (Bandung: Alfabeta, 2018), 1.

${ }^{2}$ Pandangan Soepomo terhadap definisi hukum adat dikutip dalam buku "Intisari Hukum Adat Indonesia Dalam Kajian Kepustakaan" yang ditulis oleh Tolib Setiady,... 15. 
dilakukan oleh masyarakat Maninili Barat, karena diyakini memberikan kehidupan yang baik. ${ }^{3}$

Penelitian ini merupakan jenis penelitian deskritif dengan pendekatan kualitatif. Dengan metode ini penelitian akan memberikan gambaran secara sistematis materi-materi pembahasan dari berbagai sumber tentang keadaan yang terjadi pada objek penelitian kemudian dianalisis secara tepat dan cermat guna memperoleh sebuah kesimpulan penelitian tentang pandangan hukum Islam terhadap adat topo salia di Desa Maninili Barat Kecamatan Tinombo Selatan Kabupaten Parigi Moutong.

Berangkat dari latar belakang tersebut, maka penelitian ini memfokuskan pada permasalahan tentang pelaksanaan adat topo salia di Desa Maninili Barat Kecamatan Tinombo Selatan Kabupaten Parigi Moutong dan bagaimana pandangan Hukum Islam terhadap adat topo salia.

\section{B. Tradisi Topo salia Pada Masyarakat Desa Maninili Barat}

Adapun konsep palaksanaan topo salia tetap mengacu pada adat yang berlaku secara umum di dalam suku tajio, yakni selalu mengutamakan syarat dan ketentuan seperti: keturunan, agama, umur dan sebagainya. Menurut ketentuan adat istiadat disebut porosong tevayo yang artinya menghilangkan yang kotor serta joanya nelengkap tehidup ane joonya tehadat eini. Sehingga makna dalam pelaksanaan topo salia dianggap suci, sehingga harus dimuliakan. Untuk memuliakannya perlu dilaksanakan secara bertahap dan teratur agar adatnya lengkap dan tidak berkurang. Bentuk pelaksanaan topo salia terdiri tiga langkah yakni, persiapan, pelaksanaan dan penutup.

1. Persiapan tiga hari sebelum menjelang pelaksanaan topo salia terdiri dari mengadakan musyawarah dengan beberapa dewan adat yang ada di desa Maninili dan tokoh masyarakat serta tuan rumah yang akan menyelenggarakan acara tersebut. Mendirikan gianan (sabuah), megaga atau mengedarkan

${ }^{3}$ Nur Fatni Daeng Mapato, Bentuk Penyajian Kakula Dalam Tradisi Topo Salia Di Desa Maninili Kecamatan Tinombo Selatan Kabupaten Parigi Moutong, Skripsi tidak diterbitkan, (Gorontalo: Universitas Gorontalo, 2016), 2. 
undangan yang berlaku 3 hari sebelum menjelang acara pelaksanaan baik undangan lisan maupun tulisan. Membuat febuntuang atau tempat yang digunakan bagi peserta adat saat melakukan prosesi adat. Membuat lanjara atau disebut tangga. ${ }^{4}$

2. Pelaksanaan topo salia terdiri dari tahapan yang harus dilakukan peserta adat seperti:

a) Tahap Nondiis (mandi masal).

Tahap ini merupakan tahap awal dalam topo salia, masingmasing anak dari umur 3 sampai 6 tahun akan dibawah ke sungai untuk dimandikan secara masal oleh pemangku adat yang disebut ina. Tujuan dari tahap ini agar anak-anak agar lebih bersemangat setelah dimandikan dan makna yang dapat diambil adalah agar jiwa anakanak akan sehat.

b) Tahap Momakei atau sering disebut didandan

Dalam tahap ini akan terlihat jelas peran orang tua akan berlombah-lombah untuk mendandani anak-anak mereka satu persatu agar terlihat tampan dan cantik. Diawali dengan memakaikan baju adat hingga memakaikan perlengkapan baik itu aksesoris berupa gelang, kalung, cincin bagi anak perempuan dan untuk aksesoris anak laki-laki terdiri dari ikat pinggang, kris, dan sarung adat.

c) Febuntuang (tempat duduk)

Tahap ini sering disebut tahapan persetaraan antara sesama manusia. Febuntuang (tempat duduk) terbuat dari bambu kuning yang disebut tiol, keistimewaan dari tahap ini adalah anak-anak yang diusung dengan menggunakan tempat duduk tandanya masih mewarisi keturunan dari raja dan yang tidak diusung tidak mewarisi keturunan raja.

d) Naik pelaminan,

Tahap ini merupakan tahap terakhir dari seluruh rangkaian adat topo salia dimana dalam tahap ini disebut intih dari seluruh tahapan sebelumya, setelah melalui 7 kali putaran mengelilinggi rumah atau mesjid akan diturunkan tepat didepan pintu dan akan akan naik keatas pelaminan atau tempat duduk setelah selesai dihadat.

${ }^{4}$ Darwis Daeng Mapato, Ketua Adat Kecamatan Tinombo Selatan "Wawancara” Rumah Kepala Adat, tanggal 24 September 2019 
3. Rangkaian terakhir disebut rangkaian adat inti yakni momporosong

Dalam pelaksanaannya secara bergiliran anak-anak akan dipanggil untuk momporosong, sesajian yang digunakan untuk melengkapi adatnya terdiri dari piring putih yang didalamnya berisi beras mentah berwarna kuning disebut tebea nelili, serta terdapat tiga buah telur disebut teitolu, terdapat sebuah batu disebut vatu, dan tiga lilin disebut tetaru. Sangat penting untuk dilaksanakan tahap ini karena bermakna untuk kekuatan dan kebersihan diri anak-anak agar dijauhkan dari bencana. ${ }^{5}$

Alat musik kakula menjadi pelengkap dari pelaksanaan topo salia yang juga merupakan sebagian dari hukum adat yang ada di Desa Maninili Barat secara menyeluruh. Hal ini terlihat jelas setiap urutan pelaksanaannya memiliki arti sendiri. Berdasarkan wawancara dengan Darwis Daeng Mapato tanggal 24 september 2019 dalam pembicaraan yang harus dijalankan bahwa adat dan agama tidak bisa ditinggalkan dari kehidupan manusia. Dan ia menegaskan bahwa "jio anya nambosi te hidup ane jio anya tehadat". (tidak akan bagus hidup kalau tidak ada adat) hal sama diungkapkan oleh Muslimin salah satu totua tomogurang nu kampung atau orang tua kampung:

"Bahwa adat merupakan sesuatu yang tidak bisa dipisahkan dalam kehidupan manusia Setitik air yang ada dalam kandungan dan sampai manusia lahir didunia, adat akan tetap ada dalam kehidupan manusia".

Pelaksanaan kakula dalam tradisi topo salia dimulain 10.00 WIB sampai dengan selesai, ang memainkan music itu adalah kaum perempuan yang sudah berkeluarga dan merupakan seniman yang biasa memainkan tersebut dalam tradisi topo salia. Dan sebelum mementaskan musik ini seluruh persiapannya baik bentuk penyajiannya yang meliputih rias dan kostum, skema penyajian dan semua kebutuhan yang diperlukan terutama untuk para pemain musik yang sudah disiapkan oleh orang yang sudah ditugaskan dari hasil musyawarah sebelum acara.

${ }^{5}$ Akibia Abd. Rasyid, Ina-Ina ( Pemangku Adat) “Wawancara” rumah Pemangku Adat. Tanggal 17 September 2019 


\section{Pandangan Hukum Islam Terhadap Adat Topo salia}

Agama Islam sangat mementingkan pribadi dan keluarga ahlak yang baik, akan menciptakan masyarakat yang baik dan harmonis karena itu pula, hukum keluarga menempati posisi yang penting dalam hukum Islam. Hukum keluarga sangat erat kaitannya dengan keimanan seseorang. Seorang muslim akan selalu berpedoman kepada ketentuan-ketentuan dan peraturan-peraturan yang telah diberikan oleh Allah swt. dalam setiap pembuatan pribadi dalam hubungan dalam keluarga, sesuai dengan hakikat da'wah islamiyah, nilai-nilai Islam itu diresapi dengan penuh kedamaian tanpa meninggalkan nilai-nilai adat setempat yang telah sesuai atau tidak bertentangan dengan nilai-nilai akidah dan syariat Islam.

a. Korelasi adat topo salia dengan nilai Islam

Islam berbicara mengenai ajaran yang ideal sedangkan tradisi merupakan realitas dari kehidupan manusia dan lingkungannya. ${ }^{6}$ Adapun korelasi antara adat topo salia dengan nilai keislaman yaitu :

1) Musyawarah

Menukil dari Ibnu Arabi Al-Qurtubi mengatakan, musyawarah adalah pemersatu orang banyak, penguji otak, dan jalan menuju kebenaran'. Kemudian katanya pula Allah menganggap baik musyawarah dalam berbagai masalah, ini dia sampaikan dengan cara memuji orang-orang yang mematuhi musyawarah. ${ }^{7}$

Adapun isi musyawarah dalam Islam haruslah dilandaskan pada kesatuan pangkal otak dan kesatuan tujuan. Adapun kesatuan tujuan yang harus dicapai bersama ialah mewujudkan tujuan-tujuan syariat. ${ }^{8}$

2) Dapat mempererat tali persaudaraan

Masyarakat yang akan membangun gianan (sabuah) adalah orang-orang yang sudah ditugaskan dari hasil musyawarah sebelumnya. Dalam kegiatan ini terlihat jelas sifat sosial dan sifat

${ }^{6}$ Akhmad Taufik, dkk, Sejarah Pemikiran dan Tokoh Moderenisme Islam, (Jakarta: Raja Grafindo Persada, 2005), 44.

${ }^{7}$ Abdul Hadi Asy-syal, Islam Membina Masyarakat Adil Dan Makmur, (Jakarta:Pustaka Dian, 1987), 337

${ }^{8} \mathrm{Ibid}, 329$. 
kekeluargaan, bergotong royong masyarakat setempat untuk bekerja. Mereka dapat bertemu dalam suasana yang rukun, damai, gembira dan yang terpenting mereka sangat bersahabat satu sama lain. Upaya mempertautkan silaturahmi terdapat dalam sabda Nabi yaitu: dua orang muslim yang bertemu, lalu keduanya saling jabat tangan, niscaya dosa keduanya diampuni oleh Allah sebelum mereka berpisah. ${ }^{9}$

Dengan demikian, sesungguhnya adat topo salia merupakan salah satu sarana yang efektif untuk mempertautkan silahturrahmi antara sesama, dalam kerangka menumbuhkan kembali solidaritas anatara warga masyarakat Maninili Barat sebagai. silaturrahim salah satu ciri perilaku yang diajarkan oleh Nabi Muhammad saw. kepada para sahabat dan umatnya.

Dengan demikian aqidah Islam tidak melarang umat Islam untuk mengerjakan adat istiadat ataupun ritual, sejauh hal itu tidak bertentangan dengan nilai-nilai atau jiwa tauhid dan moralitas aqidah Islam, yang pada dasarnya juga berpangkal pada tauhid, sebaliknya adat istiadat atau ritual bid'ah dan khurafat dilarang dan harus dilenyapkan.

Dengan kata lain, ajaran Islam sesuai dan cocok untuk segala waktu dan tempat. Islam adalah agama yang dibawa oleh nabi Muhammad saw. dan dipelihara serta dipahamkan dengan rapi dan teliti sekali oleh para sahabat beliau dan orang-orang yang hidup pada zaman sahabat itu. Dan agama itu telah diperaktekkan di antara mereka demikian lamanya tanpa sengketa, tidak menyimpang kepada takwil dan tidak memerlukan adanya golongan-golongan sekte (mazhab).

Agama Islam datang dengan kepercayaan tauhid, mengesakan Allah swt. dalam zat-Nya dan perbuatan-perbuatan-Nya serta bersihNya dari serupa dengan segala makhluk. ${ }^{10}$ Sesuai firman Allah swt. dalam Al-Quran Surat Al-Ikhlas [112]:1-4, sebagai berikut:

${ }^{9}$ Ustadz Abdullah bin Taslim al-Buthni, M.A. artikel www.muslim.or.id diakses pada tanggal 24 Oktober 2019 1993), 127.

${ }^{10}$ Syekh Muhammad Abduh, Rusalah Tauhid, (Jakarta; Bulan Bintang 


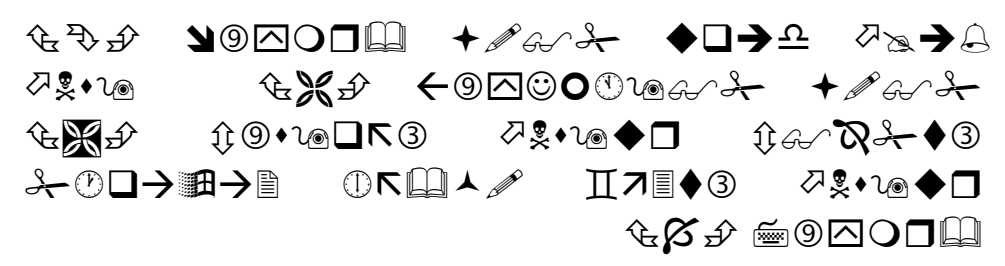

Terjemahnya:

Katakanlah: Dia-lah Allah, yang Maha Esa. Allah adalah Tuhan yang bergantung kepada-Nya segala sesuatu. Dia tiada beranak dan tidak pula diperanakkan, dan tidak ada seorangpun yang setara dengan Dia. ${ }^{11}$

Melihat dari sejarah yang ada, adat dan budaya mempunyai pengaruh yang besar dalam proses pengambilan hukum Islam. Tidak heran para ulama ushul dan fiqh menjadikan adat dan budaya sebagai acuan dalam merumuskan hukum. ${ }^{12}$

Fakta menunjukkan bahwa ada beberapa adat istiadat arab yang di adopsi dan dipelihara oleh syariat. Misalnya syarat kesepadanan pasangan (kafa'ah) dalam pernikahan, adat ini ternyata berasal dari budaya arab pra-Islam. Namun, maslahat dan tidak bertentangan dengan nash yang ada. Ini menunjukkan Islam memberikan ruang dan apresiasi terhadap norma-norma lokal sekarang tidak bertentangan dengan syariat.

Pengertian yang jelas dan terang ini juga dipegang oleh para imam mazhab dan imam umat yang diikuti. Imam Syafi'i, misalanya, seperti diriwayatkan oleh al-Baihaqi, pernah mengatakan, "perkaraperkata baru ada dua jenis: Pertama, hal baru yang menyalahi alQur'an, hadis, atsar, dan ijma; ini semua bid'ah sesat. Kedua, inovasi baru yang baik dan tidak menyalahi salah satu dari semua landasan itu. Ini adalah hal baru yang tidak tercela. ${ }^{13}$

${ }^{11}$ Al-Qur'an dan Terjemahannya (Mushaf Fatimah), (Jakarta: PT. Insan Media Pustaka, 2012), 604.

${ }^{12}$ Samsur, Tokoh Agama Di Desa Maninili Barat "Wawancara" rumah tokoh agama, tanggal 16 September 2019

${ }^{13}$ Diriwayatkan oleh al-Baihaqi dalam Manaqibasy-Syafi'i; juga oleh Abu Na'im dalm alHilyah,j.9, 113; diterjemahkan oleh Baba salem, Bukan Bid'ah m menimbang Jalan Pikiran orang-orang yang bersikap keras dalam beragama, Cet.1 (Tangerang Selatan: Ikatan Alumni alAzhar Internasional Cabang Indonesia dan Pusat studi al-Qur'an, 2012), 113. 
Tradisi -tradisi dalam masyarakat Islam yang seringkali dicap sebagai bid'ah, karena alasan masalah itu tidak ada pada zaman Rosulullah dan zaman salaf (angkatan pertama), atau karena tradisi itu hasil cangkokan tradisi masyarakat pra-Islam di Indonesia, adalah banyak sekali, seperti: Selametan, upacara-upacara pernikahan, kematian, kelahiran bayi, membangun rumah dan lain-lain. Ada diantara tradisi tersebut sudah diisi penuh dengan nilai-nilai Islam, meskipun namanya masih tetap atau sebagian penampilannya belum berubah penuh, seperti "selamatan" yang sudah dihilangkan sesajennya, diganti dengan sedekah makanan, diisi dengan membaca ayat-ayat Al-Qur'an dan doa kepada Allah swt. ${ }^{14}$

Hujjatul Islam Abu Hamid al-Ghazali ra juga pernah mengatakan, " tidak semua yang baru dilakukan (setelah Nabi saw wafat) dilarang, tetapi yang dilarang hamyalah bid'ah yang bertentangan dengan aturan agama yang tetap membantalkan suatu perkara dalam agama. ${ }^{15}$

Dalam riwayat hadis Rasulullah saw. yang diriwayatkan oleh Imam Muslim, Rasulullah saw. bersabda:

Artinya :

Barang siapa membuat tradisi baru yang baik maka baginya pahalanya dan pahala orang yang mengamalkannya hingga hari kiamat, dan barang siapa membuat tradisi buruk, maka akan menaggung dosanya dan dosa orang yang mengamalkannya hingga hari kiamat. ${ }^{16}$

Penetapan hukum berdasarkan alasan adat istiadat masyarakat mendapatkan landasan teori fiqhi yang cukup banyak antara lain kaidah fiqih:

${ }^{14} 4$ Muhammad Tholhah Hasan, Ahlussunnah Wal-Jamaah Dalam Persepsi dan Tradisi NU, (Jakarta: Lantabora Press, 2005, Cet 3), 221-222.

${ }^{15}$ Abu Hamid al-Ghazali, Ihya Ulum ad-Din, J.2. 248, diterjemahkan oleh Baba salem, Bukan Bid'ah m menimbang Jalan Pikiran orang-orang yang bersikap keras dalam beragama, Cet.1, (Tangerang Selatan: Ikatan Alumni al-Azhar Internasional Cabang Indonesia dan Pusat studi al-Qur'an, 2012), 113-114.

${ }^{16}$ Diriwayatkan oleh Muslim dalam sahih Muslim, Juz 2, 705. 


\section{لمعَادَةُ مُحَكَمَةُّة}

Artinya:

Adat atau tradisi dapat dijadikan dasar untuk menetapkan hukum syara.

Segala sesuatu yang biasa dikerjakan oleh masyarakat bisa menjadi patokan. Maka setiap anggota masyarakat dalam melakukan sesuatu yang telah terbiasakan itu akan selalu menyesuaikan dengan patokan tersebut atau tegasnya tidak menyalahinya.

Suatu penetapan hukum berdasarkan adat (urf) yang telah memenuhi syarat-syarat sebagai dasar hukum, sama kedudukannya dengan penetapan hukum yang didasarkan nas. Kaidah ini banyak berlaku pada adat-adat khusus, seperti adat yang berlaku diantara para pedagang dan berlaku didaerah tertentu, dan lain-lain.

Kaidah hukum ini tentu saja mengharuskan adanya kesesuaian dan tidak bertentangan dengan prinsip-prinsip agama atau maqashid al-syari'ah (cita-cita agama). Betapa luwes, luas, dan dinamisnya Hukum Islam jika kita bisa mengapresiasi teori ini. Imam SyihabalDin al-Qarafi (w.1285 M), tokoh besar dalam Mazhab Maliki, dalam Bukunya yang terkenal al-Furuq, mengatakan:

Melalui dalil-dalil yang dijelaskan para ulama tersebut, maka adat topo salia tidaklah bertentangan dengan Islam bahkan dibolehkan, karena mengandung nilai-nilai Islam, diantaranya musyawarah, gotong royong, mempererat tali silaturrahim, tolak bala (doa) dan bentuk syukur. Dalam adat topo salia tidak terdapat unsur menyimpang atau menyalahi syariat dalam pelaksanaan adat tersebut. walaupun adat ini tidak langsung dipraktekan oleh Rasulullah dan para Sahabat. Hal ini bukanlah menjadi tolak ukur untuk tidak melakukan adat topo salia, para ulama telah menejelaskan terkait adat yang boleh dilakukan dan tidak boleh dilakukan.

Sedangkan adat topo salia adalah upacara yang diadakan pada setiap tanggal 12 Rabiul Awal, yang salah satunya bertujuan untuk menolak balak dan menjadikan anak-anak merka beradab, berbudaya. $^{17}$

${ }^{17}$ Darwis Daeng Mapato, Ketua Adat Kecamatan Tinombo Selatan "Wawancara" Rumah Kepala Adat, tanggal 24 September 2019 
Dan juga menurut Bapak Muslimin sebagai Tokoh Agama di Desa Maninili Barat pelaksanaan adat topo salia adalah untuk memeriahkan acara Maulidan (kelahiran Nabi Muhammad saw) disetiap tahun dan pada dasarnya sebagai ungkapan rasa syukur masyarakat kepada Tuhan Yang Maha Esa. Hukum topo salia menurut sabagian masyarakat merupakan suatu kewajiban yang harus dilakukan, untuk menjauhkan sebuah musibah, seperti mendapatkan penyakit yang tiak dapat disembuhkan oleh dokter yaitu penyakit ingusan dan juga anak-anak akan menjadi nakal. Namun ada sebagian masyarakat beranggapan bahwa hukum topo salia merupakan mubah yang tidak ada paksaan didalam melakukan adat topo salia tersebut. ${ }^{18}$

Dengan demikian Islam tidak melarang umat Islam untuk mengerjakan adat istiadat ataupun ritual, sejauh hal itu tidak bertentangan dengan nilai-nilai atau jiwa tauhid dan moralitas aqidah Islam, yang pada dasarnya juga berpangkal pada tauhid, sebaliknya adat istiadat atau ritual bid'ah dan khurafat dilarang dan harus dilenyapkan.

\section{Penutup}

Dari uraian di atas, maka dapat diambil kesimpulan sebagai bagian dalam penutup ini adalah bahwa adat topo Salia dilaksanakan setiap tanggal 12 Rabiul Awal yaitu pada setiap acara memperingati maulid Nabi besar Muhammad saw. Pandangan hukum Islam terhadap adat topo salia tidaklah bertentangan dengan syariat Islam, karena mengandung nilai-nilai Islam diantaranya musyawarah, gotong royong, mempererat tali silaturahim, istilah-istilah yang berara dari kegiatan muamalah dan bentuk rasa syukur. Dalam adat topo salia tidak terdapat unsur menyimpang atau menyalahi syariat dalam pelaksanaan adat tersebut, walaupun adat ini tidak langsung dipraktekan oleh Rasulullah dan para sahabat.

${ }^{18}$ Muslimin, Tokoh Agama "Wawancara" rumah Tokoh Agama, tanggal 19 September 2019 


\section{Referensi}

Al-Qur'an dan Terjemahannya (Mushaf Fatimah), Jakarta: PT. Insan Media Pustaka, 2012.

Abd. Rasyid, Akibia, Ina-Ina (Pemangku Adat) “ Wawancara” Rumah Pemangku Adat. Tanggal 17 September 2019.

Abduh, Syekh Muhammad, Risalah Tauhid, Jakarta; Bulan Bintang 1993.

Al-Baihaqi dalam Manaqibasy-Syafi'i; juga oleh Abu Na'im dalam alHilyah, j.9, 113; terj. Baba salem, Bukan Bid'ah m menimbang Jalan Pikiran orang-orang yang bersikap keras dalam beragama, Cet.1, Tangerang Selatan: Ikatan Alumni alAzhar Internasional Cabang Indonesia dan Pusat studi alQur'an, 2012.

Al-Buthni, Abdullah bin Taslim, artikel www.muslim.or.id diakses pada tanggal 24 Oktober 2019.

Al-Ghazali, Abu Hamid, Ihya Ulum ad-Din, J.2. 248, terj. Baba salem, Bukan Bid'ah Menimbang Jalan Pikiran Orang-Orang yang Bersikap Keras dalam Beragama, Cet.1, Tangerang Selatan: Ikatan Alumni al-Azhar Internasional Cabang Indonesia dan Pusat studi al-Quran, 2012.

Daeng Mapato, Darwis, Ketua Adat Kecamatan Tinombo Selatan "Wawancara" Rumah Kepala Adat, tanggal 24 September 2019

Daeng Mapato, Darwis, Pemilik Adat Topo Salia Desa Maninili Kecamatan Tinombo Selatan, "Wawancara", Maninili : tanggal 29 juli 2019.

Daeng Mapato, Nur Fatni, Bentuk Penyajian Kakula Dalam Tradisi Topo Salia Di Desa Maninili Kecamatan Tinombo Selatan Kabupaten Parigi Moutong, Skripsi tidak diterbitkan, Gorontalo: Universitas Gorontalo, 2016.

Dahlan, Abd. Rahman, Ushul Fiqh, Jakarta: Amzah, 2011. 
Djamali, R. Abdoel, Pengantar Hukum Di Indonesia, Jakarta: Raja Grafindo Persada, 2015.

Habziz, Khairudin, Simpel Dan Mudah Menguasai 175 Kaidah Fikih, t.t: Tanwil Afkar, 2018.

Hadi Asy-syal, Abdul, Islam Membina Masyarakat Adil Dan Makmur, Jakarta:Pustaka Dian, 1987.

Muhammad, Bushar, Pengantar Hukum Adat, Jakarta: Balai Buku Ictiar, 1961.

Mukminat, Hasdalil, Adat 'Mappatamma' Dalam Pandangan Hukum islam (Studi kasus Dikecamatan Bontonompo Selatan, Kabupaten Gowa), Skripsi tidak diterbitkan Makassar: UIN Alauddin Makassar, 2015.

Muslimin, Tokoh Agama "Wawancara" rumah Tokoh Agama, tanggal 19 September 2019

Sadam, Tinjauan Hukum Islam Terhadap Pelaksanaan Adat Nandu Banja di Desa Sigenti Barat Kecamatan Tinombo Selatan Kabupaten Parigi Moutong, Skripsi tidak diterbitkan, Palu: IAIN PALU, 2014.

Samsur, Tokoh Agama Di Desa Maninili Barat "Wawancara" rumah tokoh agama, tanggal 16 September 2019.

Setiady, Tolib, Intisari Hukum Adat Indonesia Dalam Kajian Kepustakaan, Bandung: Alfabeta, 2018.

Tholhah Hasan, Muhammad, Ahlussunnah Wal-Jamaah Dalam Persepsi dan Tradisi NU, Cet ke-3, Jakarta: Lantabora Press, 2005.

* Mahasiswa dan dosen fakultas syariah IAIN Palu 